of protest against the successive surrenders to Fascism, beginning with the Anglo-German naval treaty, continuing through the farce of non-intervention to the capitulation at Munich.

As such, Langevin was inevitably a marked man after the German occupation. He had courageously refused to leave France, though he might easily have done so, and he had the honour to be arrested by the Gestapo on the basis of the Führerprincip as the most representative of all the intellectuals who had fought against Hitler. The main charges against him were his chairmanship of the Ligue des Droits de l'Homme, and because he had tried to prevent Germany from ridding itself of the Jews. He was released from prison partly as a result of the protests of French students and professors, but kept under confinement at Troyes, from which he was rescued by the Resistance after some years, and smuggled into Switzerland. $\mathrm{He}$ had to suffer more, however, from the fate of his family. His son-in-law Solomon was shot for his part in the Resistance movement, and his daughter Hélène was sent to the notorious death-camp at Auschwitz, from which, however, she managed to escape. Broken in health but not in spirit, Langevin returned to Paris after the liberation, where he took the place which had been occupied by his son-in-law in the Communist Party, and at a great meeting in the Sorbonne was accorded the homage not only of the French intellectuals, but also of the people of Paris and the fighters of the Resistance movement.

The last task of his life was the reform of education, in which he embodied his ideals of social reform. "The final objective would be to find for the individual in human society his rightful place in every respect. Society will then appear to every one of its members as a living entity in which each of us is entrusted for a while with a treasure of civilization acquired by our ancestors at the price of innumerable hardships and pains, which it is our duty to pass on after enriching it according to the extent of our ability. ... Let us hope that every child, on leaving our schools of to-morrow, will be convinced that the two moral sins of conformity and selfishness respectively oppose the double imperative duty of personal achievement and social solidarity."

The meetings which have been held in his memory in Paris and now in London serve to emphasize the growing unity of science and society throughout the world, and in particular the close ties that have been forged by the experience of recent years between the scientific workers of Britain and France. It is in furthering this unity that we can best honour the memory of Paul Langevin.

J. D. Bernal

\section{CENTENARY OF THE INSTITUTION OF MECHANICAL ENGINEERS}

\section{BY R. H. PARSONS}

$\mathrm{T}$ HE Institution of Mechanical Engineers, which has celebrated its centenary this week, can look back upon a hundred years of invaluable service both to the profession and to the community. Its existence has been contemporaneous with almost incredible developments in engineering, metallurgy and general science brought about largely by the work of its members. When it came into being, engineers had no such materials as even mild steel or aluminium, no mineral oil, no artificial abrasives, no electrical generators and no internal combustion engines of any kind. Their machine tools were comparatively few and simple, screw-threads had not yet been standardized, precision measurements were impossible, and scientific knowledge applicable to engineering problems scarcely existed. The steam engine, much as it had been left by Watt, was, however, available for industrial purposes, locomotives were running on the railways, and steam had been applied to marine propulsion.

The Institution was founded in Birmingham on January 27,1847 , by a meeting of some of the leading mechanical engineers of the day, and George Stephenson, who had taken an active part in the proceedings, was elected by acclamation as its first president. The object of the Institution, in the words of its founders, was "to enable Engineers . . . to meet and correspond, and by a mutual interchange of ideas . . to to increase their knowledge and give an impulse to inventions likely to be useful to the community at large". Birmingham was decided on as its headquarters, as being the most convenient centre for engineers engaged either directly or indirectly with the development of railways, which then constituted one of the most important fields for engineering activity.

After the death of.George Stephenson on August 12, 1848, his son Robert, who acquired the same unrivalled eminence as a railway engineer, was elected president of the young Institution. Other well-known names, such as Fairbairn, Whitworth, Penn, Armstrong, Napier and Siemens among the early presidents, bear witness to the prestige the Institution has enjoyed since its inception. In 1856 it took a step which greatly extended its influence and usefulness. This was the inauguration of its annual summer meetings, lasting two days or more, and held in some selected industrial centre or sometimes abroad. Such meetings have remained among the most appreciated functions of the Institution. An outstanding event in the history of the Institution took place in 1877, when the headquarters were transferred from Birmingham to London. At this time the membership was somewhat more than a thousand. In 1895 it began the construction of its present worthy home at Storey's Gate, St. James's Park. This was formally opened in 1899, and considerably extended in 1913. By then the Institution comprised more than six thousand members, and the rapidity of its subsequent growth is shown by the fact that at the end of last year it had almost 25,000 members of all classes, to which must now be added the considerable number of members recently admitted by the absorption of the Institution of Automobile Engineers.

The increase of membership from all parts of Britain led, in 1920, to a measure of decentralization, whereby local branches, managed by their own committees, which are represented by their chairmen on the Council of the Institution, were established in large centres of population. There are now nine such branches, covering between them the whole of Great Britain, each providing opportunities for its own discussions and other activities. Similar branches also exist in China, the West Indies and the Argentine, while advisory committees serve the interests of the Institution in seven other countries overseas. Another outcome of the increased membership has been the formation of specialized groups within the Institution. These are composed of engineers having a common 
expert interest in particular subjects, as, for example, steam, hydraulics, internal combustion engines, manufacturing, education, and so on. These groups are assisted by the Council in arranging their own meetings and discussions.

Thanks mainly to benefactions by its members, the Council of the Institution now has at its disposal valuable funds for the provision of monetary awards or medals for special lectures or particularly meritorious papers. One of its highest awards is the Watt International Gold Medal, which is bestowed biennially on some distinguished engineer, without regard to nationality, for exceptional services to science or industry. The decision is made by the Council in the light of the opinions of the leading foreign institutions, and the recipients so far have included two Englishmen, two Americans, one Australian and one Swiss. Some of the other prizes are awarded in respect of specified subjects, but in the case of others the Council has a wide discretion. Any person, for example, whether a member of the Institution or not, may be invited to deliver the well-known annual Thomas Hawksley Lecture. Lectures in this series have been delivered by such authorities as the late Sir Alfred Eddington, the late Lord Rutherford and others of similar eminence. In 1945 the Institution received the magnificent bequest of $£ 130,000$ under the will of the late Mr. James Clayton, with the condition that at least one quarter of the annual income should be used in providing a "James Clayton Prize" for the best contribution by any member in that year to modern engineering science. The first award under this bequest was made to Air-Commodore Frank Whittle for his development of jet-propelled aeroplanes.

It may fairly be claimed that no other technical organisation has so fine a record as the Institution of Mechanical Engineers in the matter of corporate research work, carried out for the benefit of the profession in general. So long ago as 1875, the Council adopted a policy of giving financial support to engineering research, and in 1879 it appointed a standing research committee to decide on and supervise such investigations as might be desirable from time to time. Very large sums have been spent by the Institution on such work, which has been carried on uninterruptedly ever since. The results of the various investigations form the basis of discussions by the members, and are then published for the benefit of all persons interested. The range of subjects is too great even for a summary here, but mention ought at least to be made of the classical experiments of Beauchamp Tower in 1882, on which the whole of the modern theory of lubrication is based, and of the work of the Alloys Research Committee which was started under the direction of Sir William Roberts-Austen in 1889 and has since been productive of immense advances in metallurgical knowledge. The Institution also took up the question of standardization at an early date, and played an active part in the establishment of the Engineering Standards Committee in 1901, to which body matters concerned with standardization have since been referred.

The Institution Library now comprises more than 35,000 volumes, arranged accessibly for consultation, and also available for loan to members who wish to borrow them. There are, in addition, some two hundred British and foreign current technical periodicals in the Reading Room. Visits to the Library or Reading Room now exceed 10,000 annually. The assistance and advice of the staff are, moreover, at the disposal of members seeking information either personally or by correspondence, and the necessary searches are carried out for them.

To maintain the high standard of qualifications required for admission to the Institution, after 1912 the election of the younger candidates was made conditional on their passing an examination in general and technical knowledge in addition to the conditions previously demanded, except in cases where the possession of an approved degree or diploma rendered any further examination unnecessary. The interest and the influence of the Institution in engineering education led to its being consulted by the Board of Trade in 1921 when the advisability of revising the old "Science and Art" examinations was under consideration. The outcome of these discussions, largely due to the late Dr. H. S. HeleShaw, was the establishment of the present system of National Certificates in Mechanical Engineering. These are granted on the result of examinations in which assessors appointed by the Institution can set up to 40 per cent of the questions, and can render compulsory any particular questions up to the same percentage of the total. The Institution thus exercises a very strong influence on the type of education given. The certificates awarded bear the signatures of the president of the Institution, of an official of the Board of Trade, and of the principal of the educational establishment concerned. The number of students who sat for these examinations in 1946 was nearly 12,000 . The Institution shows its confidence in the scheme by exempting the holder of a Higher National Certificate from further examination in the subjects covered.

In 1929 the Institution of Mechanical Engineers was granted a Royal Charter in recognition of its position as the accepted embodiment of the profession. As such it enjoys the patronage of H.M. King George VI, and, apart from the services of its individual members, it has, in its corporate capacity, rendered invaluable assistance to the Government during and since the War.

\section{OBITUARIES}

Sir Granville Orde Browne, K.C.M.G.

Str Granville St. JohN Orde Browne, who died on May 12, was a pioneer in work for the improvement of labour conditions in the British Colonies, particularly in Africa. Born in 1883, he first went to Africa as an artillery officer in the Zulu War of 1906. In 1909 he joined the administrative service in Kenya; his observations made among some of the minor tribes (Chuka, Embu, Mwimbe, Emberre) were published in 1925 in his book "The Vanishing Tribes of Kenya". Recalled to the colours in 1914, he served throughout the East African campaign, and his experience with native carriers aroused the interest in native labour which dominated the rest of his life.

Orde Browne was posted to Tanganyika in 1920 , and in 1926 became labour commissioner, the first holder in Africa of such a post. His "Report on Labour in the Tanganyika Territory", published in that year, was a landmark at a time when many employers still depended on the penal sanction for breach of contract to keep their labourers at work. Most of the points he made have become commonplaces to-day-the need for acclimatization of the labourer to his new surroundings, particularly where 